
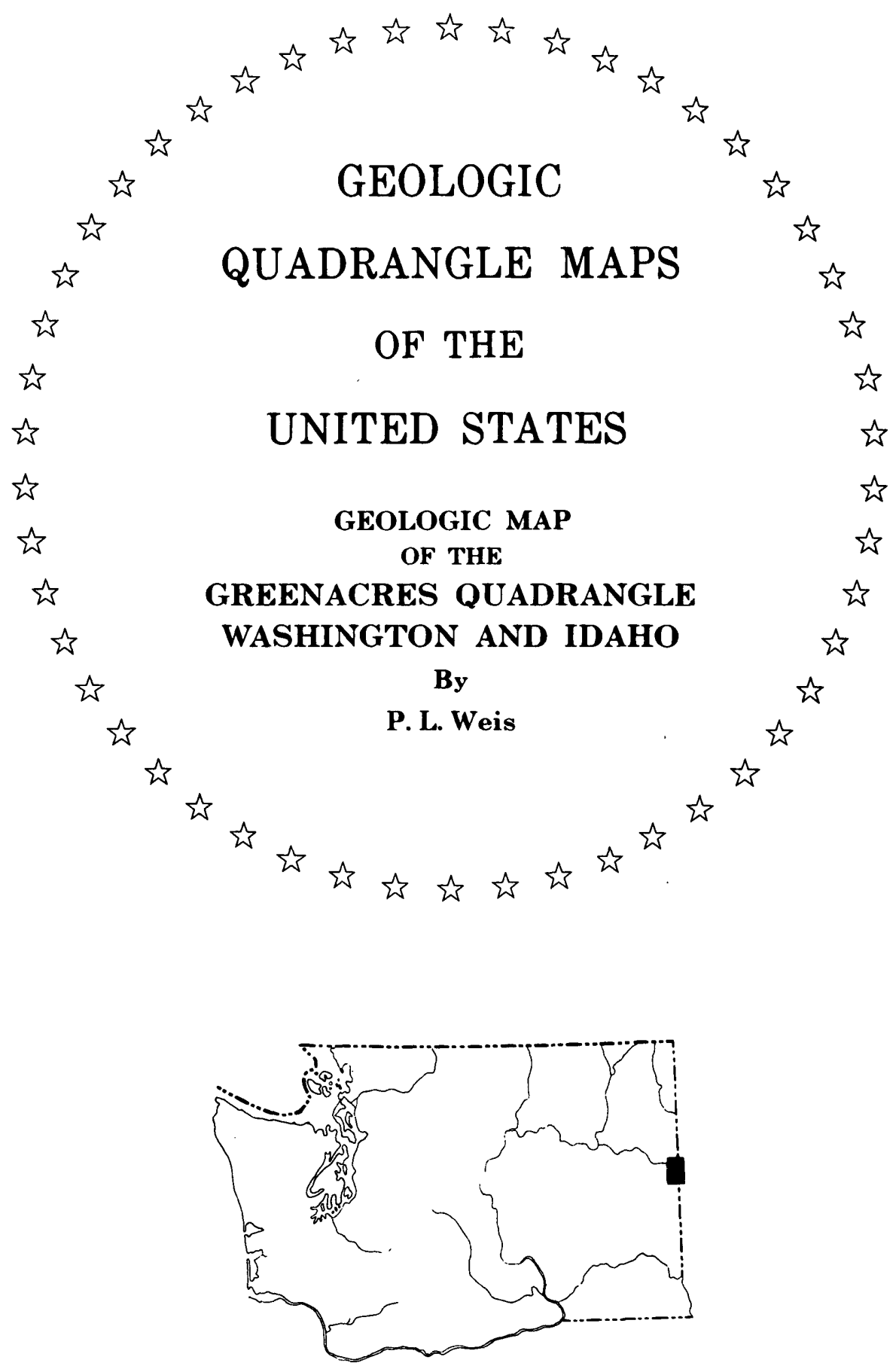

QUADRANGLE LOCATION 


\title{
GEOLOGIC MAP OF THE GREENACRES QUADRANGLE, WASHINGTON AND IDAHO
}

\author{
By P. L. Weis
}

\section{INTRODUCTION}

The Greenacres quadrangle was mapped to provide basic information on bedrock geology, origin and distribution of clay deposits, and origin and distribution of Pleistocene glacial deposits and related features. In the past, many of the older rocks were referred to as "granite" or "metamorphic rocks" without further explanation as to their age, origin, or structure. Clay deposits were presumed to occur near the margins of extrusive basalt flows, but geologic controls had not been studied in detail in this part of the Columbia Plateau. Earlier workers postulated ice margins at various places in the area, but no detailedstudies of them were made, and no work at all was done on them after the Scabland flood concept of Bretz (in Bretz, Smith, and Neff, 1956) gained general acceptance.

Previous work in the area consisted mainly of reconnaissance, most of which was concentrated on glacial features. Various aspects of the Pleistocene history of the region were considered by Alden (1953), Allison (1933), Anderson (1927), Bretz (1923, 1925, 1929), Bretz, Smith, and Neff (1956), Davis (1920), Flint $(1936,1937,1938)$, and Pardee (1942). The Latah Formation and related clay deposits were reported on by Berry (1929), Glover (1941), P a r de e and Br ya (1926), and Scheid, Hosterman, and Sohn (1945). Sand and gravel deposits were described by Leighton (1919) and the peat deposits by Rigg (1958); a seismic profile across the Spokane Valley was reported on by Newcome and others (1953); and the Palouse Formation was studied by Bryan (1927) and by Kirkham, Johnson, and Holm (1931). Anderson (1940) made a reconnaissance study of Kootenai County, Idaho, and Calkins (1909) made a brief examination of some of the bedrock exposures along the Spokane Valley.

The present study began in July 1959, and continued, with a few short recesses, until November 1963. It was resumed in March 1966. Grigg s concurrently mapped the Spokane 2-degree sheet (Griggs, 1966), which includes the Greenacres quadrangle, and A. E. Weissenborn the Mount Spokane 15-minute quadrangle, which joins the Greenacres quadrangle on the north.

\section{GEOLOGIC SETTING}

Igneous and metamorphic rocks form the foundation of the area and are partly covered by lavas and related sediments and by glacial deposits. The metamorphic rocks are part of a group of intensely metamorphosed sedimentary rocks that are found over an area about 50 miles long and about 30 miles wide. Their original age and thickness are unknown. Their deformation and metamorphism have been so in tense that individual formations are very difficult to recognize, and correlation with similar metamorphic rocks elsewhere in the region is not possible.
During Cretaceous time the metamorphic rocks were intruded by a variety of granitic rocks, most of which occur north of the Greenacres quadrangle. One alaskitic body, however, is present in the northwest part of the mapped area. This unit, like the others north of the quadrangle, is presumed to be related to the group of batholithic rocks in the Northern Rocky Mountains that are generally agreed to be of Cretaceous age.

In Miocene time, the oldest extensive basalt flows of the Columbia River Group that form the present-day Columbia Plateau were extruded. The southern and southwestern part of the quadrangle was covered, and some of the flows occupied part of the then existing Spokane Valley. At the same time, clay, silt, and sand were deposited in drainages ponded by the flows. These sediments, which now make up the Latah Formation, occur mostly near the flow margins, or upvalley from them, but in places the Latah Formation is also present in layers intertongued with the basalt.

During Quaternary time, loess was deposited almost continuously, and a lobe of a Pleistocene glacier occupied part of the Spokane Valley at least once. Erosion has since removed part or all of the loes $s$ in places, and a catastrophic flood, due to the failure of a glacial dam, extensively modified the glacial deposits in and along the valley.

\section{STR ATIGR APHY}

Precambrian rocks

The Precambrian rocks are mostly coarse-grained schist and gneiss, with minor amphibolite, local quartzite, and numerous, mostly small bodies of migmatitic, pegmatitic, and granitic material. They appear to be an intensely metamorphosed group of heterogeneous sedimentary rocks that originally ranged from mudstones to coarse sandstones in composition and were characterized by rapid, local facies changes. All are now in the sillimanite-almandine subfacies of the almandine-amphibolite facies ( $F \mathrm{yfe}$, Turner, and Verhoogen, 1958). The present mineral content probably reflects the gross composition of the original sediments. The layering that is characteristic of most of the units probably reflects approximately the original bedding. In all exposures foliation parallels the compositional layering.

Metamorphism of the Precambrian rocks was accompanied by granitization. All of the formations were affected to some degree, but some were modified more than others. Gneiss that forms an isolated outcrop in the Spokane Valley and that is questionably assigned to the Newman Lake Gneiss is apparently only very slightly affected, whereas the gneiss of Mica Peak has been extensively intruded and modified. The igneous appearing material in all of the formations is believed to be actually metamorphic in origin, that is, to be a 
product, principally or entirely, of relatively loc a l partial fusion or mobilization of the metamorphic rocks, rather than an intrusion introduced or underlying granitic magma.

Individual formations were distinguished principally on the basis of the proportions of the most abundant minerals--quartz, plagioclase, potassium feldspar, muscovite, and biotite. The presence or absence of sillimanite, a characteristic mineral in some formations and an occasional constituent in others, is also a distinguishing feature, as are the degree to which schistosity is developed, the prominence and spacing of compositional layers, the presence of quartzite layers, and the intensity of granitization. However, the overall similarity in mineralogy, textures, and metamorphic grade, together with the pronounced small-scale heterogeneity of the rocks, has made map separation of formations difficult. Structural complexity and paucity of exposures in many critical areas provide additional problems. The separation and recognition of several of the map units is therefore arbitrary; the formations mapped reflect in part only what is believed to be the most logical interpretation possible on the basis of available data.

The rapid facies changes, marked heterogeneity, and intensity of metamorphism shown in the metasedimentary rocks suggest that they are not correlative with the nearby upper Precambrian rocks of the Belt Series. No correlatives can be identified with assurance in the region, but the lithology and metamorphic grade of the rocks in the Greenacres quadrangle most nearly resembles that of the Pony and Cherry Creek Groups in southwestern Montana.

\section{Precambrian(?) rocks}

Quartz monzonite.--Small irregular bodies of intrusive quartz monzonite $c u t$ the metasedimentary rocks in many places, but only two were large enough to be shown on the map. The larger of the two, about 2 square miles in area, lies within the Hauser Lake Gneiss, northwest of the village of Newman Lake. The smaller, about a quarter of a square mile in exposed area, is about a mile north of the town of Mica.

The age of these intrusives is not known. Composition and mineralogy appear to represent a relatively narrow range, and many of the intrusives exhibit slightly to moderately developed foliation, which parallels that of the adjacent metasedimentary rocks. The intrusives are therefore tentatively considered to be approximately the same age as the period of intense metamorphism that has affected the metasedimentary rocks and therefore to represent relatively large bodies of remobilized material formed as a result of the metamorphism.

\section{Cretaceous(?) rocks}

Alaskite.--An area of about $4 \frac{1}{2}$ square miles in the northwestern part of the quadrangle is underlain by alaskitic rock. It exhibits no evidence of dynamic metamorphism, appears to crosscut the Precambrian rocks in places, and apparently was emplaced after the period of intense metamorphism that affected the Precambrian metasedimentary rocks. A. E. Weissenborn (oral commun., 1960) has tentatively correlated this intrusive rock with similar rocks to the north in the Mount Spokane quadrangle considered to be of Cretaceous age.

\section{Tertiary rocks}

The Columbia River Group and the Latah Formation occur in several places in the Greenacres quadrangle, but the most extensive exposures are in the northwest and south. The Columbia River Group is represented by an unknown number of basalt flows; at least two can be recognized near Manito, where the lower flow was weathered to a depth of approximately 50 feet before deposition of the overlying flow (J.W. Hosterman, oral commun., 1960), and at Shelly Lake, where two flows are separated by sedimentary rocks of part of the Latah Formation. Pillow lavas and palagonite tuff di e exposed in a roadcut at the west edge of the town of Valleyford.

The original extent of both the Columbia River Group and the Latah Formation was much greater in the Spokane Valley than at present, as shown by erosional remnants in a number of places and at several elevations. Seismic data (Newcomb and others, 1953) and well logs (Pardee and Bryan, 1926) indicate that the Latah Formation occupies the Spokane Valley at depths of about 400 to 1,100 feet. Deposition of these rocks drastically modified surface drainage throughout the region (Anderson, 1927).

\section{Quaternary deposits}

The Quaternary history of the Green acres quadrangle is complex. Repeated periods of glaciation during the Pleistocene affected the Spokane Valley and its tributaries, and a lobe of glacial ice advanced into the Greenacres quadrangle at least once, probably in early Bull Lake (early Wisconsin) time (Richmond and others, 1965; Weis and Richmond, 1965). Glacial lakes occupied Spokane Valley at least twice, once in Bull Lake time and again in Pinedale (late Wisconsin) time. Catastrophic floods occurred when water impounded in glacial Lake Missoula breached its ice dam at the mouth of the Clark Fork River in Idaho, some 60 miles to the northeast, and swept southwest through Spokane Valley (Bretz, Smith, and Neff, 1956). Thick loes s deposits were formed on the Columbia Plateau and to a lesser extent in adjacent areas.

In many places the deposits now present were formed by more than one process. Disaggregation, weathering, and mass-wasting of residuum produced colluvium, in which loess was incorporated in varying amounts. Colluvial and loessal deposits were partly eroded and transported to form part of the lake sediments in the glacial lakes. Ice-margin deposits from the glacial lobe merged with glacial lake beds, and ice-rafted boulders and cobbles were distributed everywhere below the upper limits of the meltwater. Outwash deposits filled the main part of Spokane Valley to depths of hundreds of feet. The catastrophic floods that swept through the area reworked much of the preexisting material and formed new deposits in many places.

In places each of the deposits of various origins merges with, or has been mixed with, other deposits of different origin. The distinctions made in mapping are therefore necessarily arbitrary in many places, as are the boundaries between units. An effort was made to classify each of the Quaternary formations on the basis of its dominant composition or most probable origin, but the distinctions are not always clear cut, and in some places the position or form of the formation, rather than the composition, was considered to be of greatest significance.

Age of the rocks in the Greenacres quadrangle

The ages of most of the rocks in the quadrangle are not known with accuracy, but some data are available to indicate probable ages of certain units.

Two zircon samples were separated from metamorphic units for lead-alpha age determinations. Sample 1W7 is from the Hauser Lake Gneiss at the southeast corner of Newman Lake, Washington, in the Mount Spokane quadrangle, Washington-Idaho. Sample $1 \mathrm{~W} 8$ is from gneiss at Chester Creek in sec. $9, T .24$ N., R. 44 E., Greenacres quadrangle, Tom W. Stern, U.S. Geological Survey, reported the following results from those samples: 


$\begin{array}{cccc}\text { Field No. } & \frac{\alpha / \mathrm{mg}-\mathrm{hr}}{227} & \frac{\mathrm{Pb}(\mathrm{ppm})}{117} & \frac{\text { Calculated age }}{1150 \pm 130 \mathrm{~m} . \mathrm{y}} \\ 1 \mathrm{~W} 7 & 227 & 125 & 1120 \pm 130 \mathrm{~m} . \mathrm{y} .\end{array}$

$1 /$ Lead determinatión by Harold Westley. All values are averages of duplicate determinations.

2/Ages were calculated from the following equations: (1) $\mathrm{t}=\mathrm{CPb} / \alpha$,

where $t$ is the calculated age in millions of years, $C$ is a constant based upon the Th- $\mathrm{U}$ ratio, $\mathrm{Pb}$ is the lead content in parts per million, and $\alpha$ is the alpha counts per milligram per hour.

(2) $\mathrm{T}=\mathrm{t}-\frac{1}{2} \mathrm{kt}^{2}$,

where $T$ is the age in millions of years corrected for decay of uranium and thorium, and $\mathrm{k}$ is a decay constant based upon the Th-U ratio.

The following constants were used:

$\begin{array}{ccc}\text { Assumed Th-U ratio } & \underline{\mathrm{C}} & \underline{\mathrm{K}} \\ 1.0 & 2485 & 1.56 \times 10^{-4}\end{array}$

Age is rounded off to the nearest $10 \mathrm{~m} . \mathrm{y}$. The error quoted is that due only to uncertainties in analytical techniques.

Petrographic examination of the zircon and the containing rocks led to the conclusion that the zircon most probably formed during the period of intense metamorphism that affected these rocks. The age determinations are therefore interpreted as representing the minimum age of the metamorphism. The time at which the sediments were laid down is not known.

In 1959, a concentrate of mona $z$ ite was made by Robert G. Coleman, of the Geological Survey, from granitic rock collected at the Daybreak uranium mine in the Mount Spokane quadrangle. The lead-alpha age of the monazite was determined by Tom W. Stern of the Geological Survey to be $75 \pm 10 \mathrm{~m}$.y. The granitic rock resembles the alaskite that is found in the Greenacres quadrangle (A. E. Weissenborn, oral commun., 1960 ), and the sample is believed to be representative of the igneous rocks intruded into the area at some time after the Precambrian period of metamorphism.

Several potassium-argon age determinations have been made during the past few years on basalt from the Columbia River Group. Evernden and James (1964) reported an age of $14.5 \mathrm{~m}$.y. for a basalt flow 8 miles south of Spokane. Jane Gray and L. R. Kittleman (written commun., 1966) obtained basalt samples from several places on the Columbia Plateau for age determinations by the K-Ar method. Two samples c a me from the Greenacres quadrangle. One, from the basalt flow that caps the hill about half a mile southeast of Shelly Lake, south of Veradale, has an age of $20.1 \mathrm{~m} . \mathrm{y}$. Another sample, from a dike cutting the Latah Formation below and north of the other dated basalt flow, has an age of $7.7 \mathrm{~m} . \mathrm{y}$. The data now available indicate that the basalt flows were extruded over a long period of time. Not enough data are available as yet to permit accurate age assignments for individual flows exposed in the quadrangle.

\section{STRUCTURE}

The structures of the Precambrian rocks in the Greenacres quadrangle suggest that they represent three distinct groups. Although all three groups exhibit intense small-scale deformation in many places, formation contacts and overall attitudes appear to form a broadly consistent pattern within each group.

On the north side of Spokane Valley, the Hauser Lake and Newman Lake Gneis s e trend generally northeast and dip gently to moderately northwest. They extend for several miles to the north, in the Mount Spokane quadrangle (A. E. Weissenborn, oral commun., 1960). South of Spokane Valley, the group of formations extending from Chester Creek on the west to Cable Peak on the east trend generally northwest. Layering and foliation is flat or dips gently west along the west side of the quadrangle but appears to have an average dip of about $45^{\circ}$ to $55^{\circ} \mathrm{W}$. throughout the rest of the area. North of these formations, the area mapped as metamorphic rocks, undivided, has no clear-cut overall attitude. Local variations are complex and do not appear to be related to the formations farther south.

\section{Faults}

Two faults are shown on the geologic map. No actual breaks in the rocks were seen in the field; the faults are proposed because of the lithologic and structural discontinuities in the rocks on opposite sides.

A major lithologic and structural change occurs along the south boundary of the area mapped as metamorphic rocks, undivided. On the north side of that boundary, lithology and structure are complex and apparently without a clear-cut pattern. To the south, the lithologic units and overall structural patterns appear to form an internally coherent picture. The abrupt change appears most readily explainable by assuming that it is a fault contact. The absence of a recognizable fault trace suggests that if there was faulting, at least some displacement occurred before the end of the period of intense metamorphism that affected the rocks.

A second fault is indicated along part of California Creek, where a distinctive quartzite layer south of the creek ends abruptly at the creek bottom. Gneiss of Mica Peak crops out on the north side of the creek and on the low ridge to the north and northwest. Field relations could be explained by either a left-lateral movement on a tear fault or by the dropping of the south side of a steeply dipping normal fault.

Although only two major faults are shown on the map, geologic evidence suggests that another may exist, concealed by the thick fill of younger material in the Spokane Valley. Although the lithology and metamorphic grade of the Precambrian rocks are similar on opposite sides of the valley, no mappable units could be correlated across the valley. Furthermore, the units north of the valley trend northeastward, whereas those south of the valley trend northwest, almost at a right angle. This structural and lithologic difference at least suggests a major break, a possibility further suggested by the topographic break represented by the valley itself.

The ridge east of Chester Creek and the northernmost part of the second ridge to the east are cut by several straight, deep notches. Most are about 15 to 40 feet wide and range from 15 to 30 feet in maximum depth. Several small springs, seeps, or damp areas occur within the notches a few hundred feet downhill from the ridge crests. Most of the notches can be traced only a few hundred feet. The area in which the notches occur is well below the maximum level reached by the catastrophic floods of Pleistocene time. The topography suggests that the notches were underlain by rocks more easily eroded than those in adjacent areas and that they were scoured out by the flood. The seeps and springs suggest that the notches are underlain by brecciated zones. No breccia is exposed, however, and no evidence of displacement could be recognized on opposite sides of the notches.

\section{ECONOMIC GEOLOGY}

Clay and silty clay of the Latah Formation have been mined in the Greenacres quadrangle. The most extensive exploitation is immediately north of the town of 
Mica, where the clayey deposits are mined for use in the brick and tile plant at Mica. Clay from the Somers pit, about 2 miles south of Opportunity, is also mined and trucked to the plant at Mica.

The only other active quarry in the Latah Formation is about half a mile southeast of Shelly Lake, south of Veradale, where silty clay beds are mined by the Ideal Cement Co. for use in making Portland cement.

Clay has been mined in the past from other pits near Freeman, where clay from the Latah Formation and intensely weathered parts of the gneiss near Chester Creek have both been used to produce brick.

The reserves of usable clay remaining in the Latah Formation and in nearby, intensely altered igneous and metamorphic rocks are not precisely known but must be large, probably on the order of tens of millions of tons. Although the character and quality of the clay are probably not uniform, the amount usable for the manufacture of brick, tile, and related products is undoubtedly sufficient for many years' supply at present or foreseeable rates of extraction.

The large, widespread deposits of sand and gravel of Pleistocene age in and near Spokane Valley have been quarried in many places. Most has beenused for road building and as aggregate in a variety of concrete structures. Remaining reserves are extremely large.

\section{REFERENCES}

Alden, W. C., 1953, Physiography and glacial geology of western Montana and adjacent areas: U.S. Geol. Survey Prof. Paper 231, 200 p.

Allison, I. S., 1933, New version of the Spokane flood: Geol. Soc. America Bull., v. 44, no. 4, p. 675-722.

Anderson, A. L., 1927, Some Miocene and Pleistocene drainage changes in northern Idaho: Idaho Bur. Mines and Geology Pamph. 18, 29 p.

1940, Geology and metalliferous deposits of Kootenai County, Idaho: Idaho Bur. Mines and Geology Pamph. 53, 67 p.

Berry, E. W., 1929, A revision of the flora of the Latah formation: U.S. Geol. Survey Prof. Paper 154-H, p. 225-265.

Bretz, J. H., 1923, The channeled scablands of the Columbia Plateau: Jour. G e ology, v. 31 , no. 8, p. 617-649.

1925, The Spokane flood beyond the channeled scablands: Jour. Geology, v. 33, no. 2, p. 97-115; no. 3 , p. 236-259.

1929, Valley deposits immediately east of the channeled scabland of Washington: Jour. Geology, v. 37 , no. 5 , p. 393-427; no. 6. p. 505-541.

Bretz, J. H., Smith, H. T. U., and Neff, G. E., 1956 , Channeled scabland of Washington--new data and interpretations: Geol. Soc. America Bull., v. 67, no. 8, p. 957-1049.

Bryan, Kirk, 1927, The "Palouse soil" problem, with an account of elephant remains in wind-borne soil on the Columbia Plateau of Washington: U.S. Geol. Survey Bull. 790-B, p. 21-45.

Calkins, F. C., 1909, A geological ręconnaissance in northern Idaho and northwestern Montana, with notes on the economic geology by D. F. MacDonald: U.S. Geol. Survey Bull. 384, 112 p.
Davis, W. M., 1920, Features of glacial origin in Montana and Idaho: Assoc. Am. Geographers Annals, v. 10 , p. 75-147.

Flint, R. F., 1936, Stratified drift and deglaciation of eastern Washington: Geol. Soc. America Bull., v. 47 , no, 12 , p. 1849-1884.

1937, Pleistocene drift border in eastern Washington: Geol. Soc. America Bull., v. 48, no. 2, p. 461-523.

1938, Origin of the Cheney-Palance scabland tract, Washington: Geol. Soc. America Bull., v. 49, no. 3, p. 461-523.

Fyfe, W. S., Turner, F. J., and Verhoogen, John, 1958, Metamorphic reactions and metamorphic facies: Geol. Soc. America Mem. 73, 259 p.

Glover, S. L., 1941, Clays and shales of Washington: Washington Div. Mines and Geology Bull. 24,368 p.

Griggs, A. B., 1966, Reconnaissance geologic map of the west half of the Spokane quadrangle, Washington and Idaho: U.S. Geol. Survey Misc. Geol. Inv. Map I-464, scale $1: 125,000$.

Kirkham, V. R. D., Johnson, M. M., and Holm, Donald, 1931, Origin of Palouse Hills topography: Science, n.s., v. 73, no. 1886 , p. 207-209.

Leighton, M. M., 1919, The road building sands and gravels of Washington: Washington Geol. Survey Bull. 22, $307 \mathrm{p}$.

Newcomb, R. C., and others, 1953, Seismic cross sections across the Spokane Valley and the Hillyard Trough, Idaho and Washington: U.S. Geol. Survey open-file report, $15 \mathrm{p}$.

Pardee, J. T., 1942, Unusual currents in glacial Lake Missoula, Montana: Geol. Soc. America Bull., v. 53, no. 11 , p. 1569-1599.

Pardee, J. T., and Bryan, Kirk, 1926, Geology of the Latah Formation in relation to the lavas of the Columbia Plateau near Spokane, Washington: U.S. Geol. Survey Prof. Paper 140-A, p. 1-16.

Richmond, G. M., Fryxell, Roald, Neff, G. E., and Weis, P. L., 1965, The Cordilleran ice sheet of the Northern Rocky Mountains, and related Quaternary history of the Columbia Plateau, in Wright, Jr., H. E., and Frye, D. G., editors, The Quaternary of the United States, A review volume for the VII Congress of the International Association for Quaternary Research: Princeton, N. J., Princeton Univ. Press, p. 231-242.

Rigg, G. B., 1958, Peat resources of Washington: Washington Div. Mines and Geology Bull. 44, 272 p.

Rigg, G. B., and Gould, H. R., 1957, Age of Glacier Peak eruption and chronology of postglacial peat deposits in Washington and surrounding areas: Am. Jour. Sci., v. 255, no. 5, p. 341-363.

Scheid, V. E., Hosterman, J. W., and Sohn, I. G., 1954, Excelsior high-alumina clay deposit, Spok a n County, Washington: U.S. Geol. Survey open-file report, $77 \mathrm{p}$.

Weis, P. L., and Richmond, G. M., 1965, Maximum extent of late Pleistocene Cordilleran glaciation in northeastern Washington and northern Idaho: U.S. Geol. Survey Prof. Paper 525-C, p. C128-C132. 